\title{
Misunderstanding the Other and Shy Signs of Openness: Discourse on the 1992-1995 War in the Current Bosniak and Bosnian Serb Media
}

\author{
MICHAL JANÍČKO ${ }^{1}$
}

\begin{abstract}
The article deals with how the 1990s civil war in Bosnia and Herzegovina was represented in the media that currently remain influential among Bosniaks and Bosnian Serbs. Critical discourse analysis is used both as a theoretical approach to discourse and as a methodological tool for its study. In the analysis, the civil war discourse in Bosniak and Bosnian Serb media is represented by two daily newspapers on each side. The analysis reveals mutually incompatible representations of the causes and nature of the war, the prevailing absence of dialogue, and the unwillingness of each side to consider the other side's war victims. Looking at more specific topics, a number of discourses are identified on both sides, among which some present the potential for dialogue with alternative representations. The discourses are interpreted through Bosniak and Bosnian Serb nationalist ideologies. The findings might support further research on the relation between the media and nationalism and on the ongoing Bosnian political dispute concerning the desired nature of the state.
\end{abstract}

Keywords: Bosnia and Herzegovina, Bosniaks, Serbs, Media, Discourse Analysis, Nationalism

\section{Introduction}

With roughly 100,000 victims, the 1992-1995 civil war in Bosnia and Herzegovina $(\mathrm{BiH})$ was, in the broader context of the dramatic breakup of Yugoslavia, the bloodiest conflict in Europe since 1945 (Zebić 2013; Zwierzchowski, Tabeau 2010). The range of the conflict was surprising, as, throughout the existence of the socialist Yugoslavia, BiH never witnessed ethnically motivated violence among

\footnotetext{
${ }^{1}$ Fond dalšího vzdělávání (Fund of Further Education), Na Maninách 7, 170 00, Praha 7, Czech Republic. E-mail: michal.janicko@gmail.com. The article is based on the findings of the author's master thesis "Nationalist Discourse in Bosnia and Herzegovina: Civil War Images from 19921995 in Current Bosnian-Serb and Bosniak Media“, defended at Department of Sociology, Faculty of Arts, Charles University in Prague, Czech Republic.
} 
its mixed nations and, as research has continuously shown, exhibited a low level of ethnic distance when compared to other parts of Yugoslavia (Puhalo 2009: 12 14). The consequences of the war are still very present in the country, most visibly in that the inter-entity border inside of $\mathrm{BiH}$ largely copies the front line from 1995, when peace was restored. Today, Bosnian society is divided along ethnic lines almost as deep as those which existed right before the war.

It has been shown many times that the mass media can play an important role in sparking and maintaining an atmosphere of conflict in society, as in the specific case of the 1990s Balkan wars (Kolstø 2009, Thompson 2000, Kurspahić 2003). This article seeks to examine how the current Bosniak and Bosnian Serb media reflect on the 1992-1995 civil war in the country. It identifies the main features of the current discourse present in the media which are influential in each nation and interprets the identified discourses from the perspective of Bosniak (formerly Muslim) and Serb nationalist ideologies, while keeping in mind the media's background and the broader social context of $\mathrm{BiH}$. Because of the limited space for this article, I have opted to deal only with the two more populated and institutionally stronger Bosnian nations, whose mutual conflict was the core of the 1990s war. In future research it would nevertheless be useful to include the perspective of Bosnian Croats as well in order to reach a more complete understanding of the topic.

While there is some scholarly material on the 1990s media coverage of the Bosnian war (Kolstø 2009), more works approach the topic in a rather journalistic fashion (Kurspahić 2003, Thompson 2000). Concerning the current content of the media in $\mathrm{BiH}$, a number of studies by Bosnian analysts observe deep divisions between the Bosniak, Serb and Croat media (Džihana 2012, Tešanović 2012, Udovičić 2010, Turčilo 2010) without, however, the ambition to systematically research media content. This analysis seeks to identify specific structures inside the Bosniak and Bosnian Serb war-related discourses and their relation to nationalist ideologies. In this way, I hope to contribute to a deeper understanding of the differences both between and within the two largest Bosnian nations regarding their attitude towards the recent past and to their future coexistence.

\section{Consequences of the Bosnian war and the current political situation}

In the socialist era, Bosnia and Herzegovina, ethnically composed mainly of Muslims, Serbs and Croats, witnessed no ethnic conflicts (see Figure 1). 
Figure 1: Ethnic composition of $\mathrm{BiH}$ according to the 1991 census

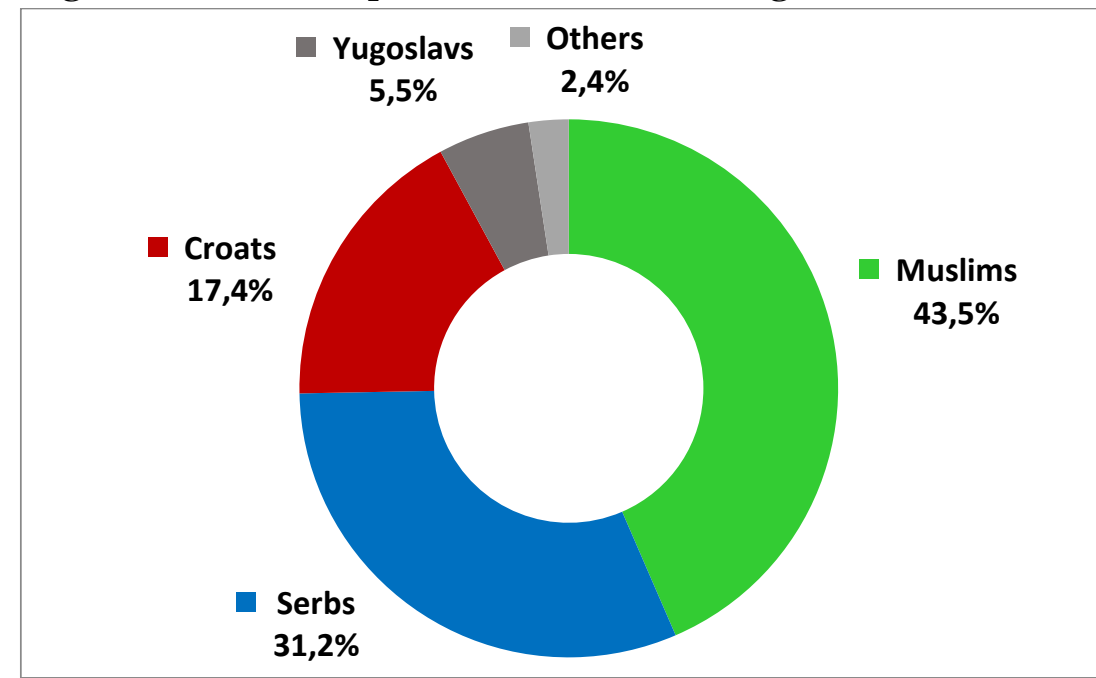

Source: Državni zavod za statistiku Republike Bosne i Hercegovine (1993)

Tensions however heightened in the early 1990s on the back of the breakup of Yugoslavia. While there were no ethnic conflicts in $\mathrm{BiH}$ after the Second World War, tensions heightened in the early 1990s on the back of the breakup of Yugoslavia. Following the Slovenian and Croatian exit from the federation, Muslim and Croat political elites in $\mathrm{BiH}$ opted for the same goal for $\mathrm{BiH}$, while Bosnian Serb leaders strove to preserve a joint state with Serbia and Montenegro. Despite the resistance of Serb deputies, the Bosnian parliament declared a plebiscite which, with most Serb voters abstaining, approved the country's declaration of independence. About a month later, the war broke out, as armed units of Bosnian Serbs, initially with the support of the Yugoslav People's Army, took control of a number of cities and, later, of most of the country. During the war the Army of Republika Srpska (Vojska Republike Srpske, VRS) fought against the mostly Muslim/Bosniak Army of $\mathrm{BiH}(\mathrm{ARBiH})$ and the Bosnian Croat Army; the latter two were, however, for some time also engaged in a mutual conflict. The war ended with the signing of the Dayton Peace Accords in November 1995 after NATO twice bombed Bosnian Serb positions and Muslim-Croat forces subsequently seized a large stretch of territory previously held by VRS. The peace accords confirmed $\mathrm{BiH}$ as an independent state with secure borders but at the same time recognized two autonomous entities within the country: the Federation of Bosnia and Herzegovina $(\mathrm{FBiH})$, with mostly Bosniak (formerly Muslim) inhabitants, and Republika Srpska (RS. Only few powers remained with the central Bosnian institutions.

The Bosnian war was particularly savage. Two surveys of war victims, one conducted by the Research-Documentary Centre of Mirsad Tokača in Sarajevo 
and the other by Jan Zwierchowski and Ewa Tabeau for the International Criminal Tribunal for the Former Yugoslavia, found that the number of people killed during the war reached close to 100,000 (see Table 1).

Table 1: Casualties of the 1992-1995 Bosnian war

\begin{tabular}{|c|c|c|}
\hline & $\begin{array}{c}\text { Zwierzchowski, } \\
\text { Tabeau, 2010 } \\
\text { (ICTY) }\end{array}$ & $\begin{array}{c}\text { Research- } \\
\text { documentary } \\
\text { Centre, 2013 }\end{array}$ \\
\hline Total & $\mathbf{1 0 4 7 3 2}$ & $\mathbf{9 5 9 4 0}$ \\
\hline Muslims & $65 \%$ & $65 \%$ \\
\hline Serbs & $22 \%$ & $26 \%$ \\
\hline Croats & $8 \%$ & $9 \%$ \\
\hline Others & $5 \%$ & $1 \%$ \\
\hline
\end{tabular}

Source: Zwierzchowski, Tabeau (2010), Filipović (2013)

Among the three parties of the conflict, Muslims suffered the most. The differences between numbers of casualties by ethnicity grow even wider when only civilians are taken into account. Among these, the proportion of Muslims was, according to Zwierchowski and Tabeau, 69\% and according to the Research-Documentary Centre, as much as $82 \%$.

Nowadays, the constitution contained in the 1995 Dayton Peace Accords is still in force, making $\mathrm{BiH}$ a country composed of the two entities which was effectively founded in the war. Bosniak political leaders continuously strive to weaken and ultimately dismantle RS, while Bosnian Serb elites oppose such a move, sometimes using separatist rhetoric. It often occurs that some vital institutions fail to function because one of the three national leaderships blocks their work; in addition, the media space is full of mutually incompatible demands from politicians representing the three main ethnicities. To compound matters, the Bosnian economy performs very badly, unemployment is extremely high (Srna 2014), and gaps in the public budget are filled only by new loans. Poverty threatens two thirds of the inhabitants, every sixth suffers from malnutrition, and living standard indicators are rapidly deteriorating (Nikolić 2013, Tanjug 2014).

Since the end of the war, there has been peace in $\mathrm{BiH}$ and no extensive ethnically motivated violence has occurred. However, the war and the mass expulsions that took place in the course of it caused vast movements of people. As a result, in contrast to the earlier heterogeneous distribution of the population, Bosniaks, Serbs and Croats nowadays live mostly apart, surrounded only by members of their respective communities. Today, unlike before the war, all of the largest cities such as Sarajevo, Banja Luka, Tuzla, Zenica, and Bijeljina are virtually homogenous, except for Mostar, where, nevertheless, the approximately equal 
Bosniak and Croat populations are de facto separated from each other (e.g. Behram 2014).

\section{Current media in Bosnia and Herzegovina}

Media in $\mathrm{BiH}$ are divided along ethnic lines in terms of both their content and the audience they target. This conclusion is drawn from most analyses dealing with the Bosnian media. Amer Džihana (2012: 7) states that "both media organizations and the organization of media in Bosnia and Herzegovina have been profoundly affected by ethnocentrism [and] political clientelism"; according to Nada Tešanović (2012: 8), in $\mathrm{BiH}$ "people are trying to get to important information mainly through the media they share their ethnicity and political views with"; and the same author has also pointed out that the Bosnian media "reflect ethnic or narrow political interests, not to mention the linguistic or religious component" (Sadiković 2012). Radenko Udovičić (2010: 13) speaks of "ongoing divergent editorial policies [by the Bosnian public broadcasters] that (...) are to a large extent ethnically and politically antagonistic". Also, Lejla Turčilo (2010) sees the Bosnian media as ethnically divided and, in this respect, as "the exact image of their society". According to Davor Marko (2010: 34), Bosnian media "send their messages to discrete publics among which minimal communication doesn't take place, let alone a constructive dialogue", which results in a lack of information and knowledge about the others. These observations fully agree with surveys on the popularity of the Bosnian media. A 2013 survey by Ipsos (Istinito 2013) showed that the most trusted newspapers among FBiH's inhabitants are Dnevni Avaz (28\%), Večernji list (7\%, with a mostly Croat readership) and Oslobođenje (7\%), while in RS the most trusted dailies are EuroBlic (22\%), Press RS (16\%), and Glas Srpske (11\%). The same division along ethnic lines was found for television channels, among which the most trusted stations in FBiH and RS enjoyed almost no popularity in the other entity.

Bosniak and Bosnian Serb media act in the context of the consensus among their respective nation's political elites on the causes and nature of the civil war and on finding a desirable solution to the ethnic question in $\mathrm{BiH}$ in the future. According to Jusić (2009: 24), such a situation makes it more likely that the media will share the elites' attitudes because of a lack of other interpretational frameworks. Most of the key media on both sides are either directly controlled by nationalist political elites or maintain firm ties with them through their owners (Džihana et al. 2012). Another important feature of the Bosnian media landscape is that, according to all the available information, the Bosnian media speak to fully discrete, ethnically homogenous audiences. Therefore, there can be no doubt that the Bosnian media are divided into Bosniak, Serb and Croat outlets depending on which nationality prevails among their recipients. 


\section{Theoretical and methodological background of the research}

In what follows, critical discourse analysis as per Norman Fairclough and the nationalism theory of Richard Jenkins, built inter alia upon Fredrik Barth's ethnicity theory, are used as the theoretical and methodological frameworks for research into the current discourse of the Bosnian media on the civil war of the 1990s.

\section{a. Ethnicity, nationalism and the Yugoslav conflicts}

The theory of ethnic boundaries (Barth 1969) sees ethnicity as a changeable ascribed feature of members of a group. The identity of an ethnic group is formed by the similarities within it and according to the various distinctions from others that are regarded as important by the members. It is not possible to predict which cultural elements will play a role in ethnic differentiation because the actors themselves decide on this issue; the cultural contents of a group's self-identification change over time and so can the ethnic membership of an individual. Thus, an ethnic group is a form of social organization and is not defined by a shared culture among its members. Building on such a conceptualization, Barth concludes that an ethnic group is defined by social boundaries resulting in the dichotomization of $U s-$ the members of our ethnic group - versus Them - the members of another ethnic group. Social boundaries between ethnic groups emerge from their mutual contact and they can, though do not necessarily have to, involve residence on geographically exclusive territories. Ethnic boundaries play a major role in social interaction and all related activities of an individual. Ethnicity, similarly to gender and class, stands above most other statuses. An ethnic group persists as a relevant unit only as long as its behavior differs from another group with which it keeps in touch.

Barth's theory well suits the ethnic situation in the area of the former Yugoslavia. Language, which is usually mentioned as the main distinctive feature of an ethnic group or of a nation, does not make a difference between Serbs, Croats and Bosniaks, as they all speak the same language (for a polemic with nationalist linguists claiming the opposite see Kordić, 2010). The feature in which the three nations have historically differed is religion, which has not played such a role in the case of many other nations, e.g. Germans. Moreover, according to Kordić (2010: 209), Catholicism has been ascribed to Croatdom only since the beginning of the $20^{\text {th }}$ century. Bosniaks changed their ethnic identity even more recently. They were recognized as a nation in Yugoslavia only in the 1970s, and the current name came into official use as late as the 1990s. Meanwhile, some Bosniak elites keep trying to maintain a Bosnian ethno-national identity.

Richard Jenkins (1997) takes Barth as a starting point for his theory of nationalism. He agrees with Barth that ethnicity is negotiated through interactions between actors and that its cultural content may largely vary. He, however, asserts 
that within an ethnic group there must be a minimal level of similarity in behaviour and that the variability of an individual's ethnicity is limited by the power constellation at a given moment and in part also by previous history. Jenkins regards nationalism as one of the possible ideologies of ethnic identification, opposing Gellner's and Holshbawm's concepts of nationalism as a substitute for ethnicity. He defines nationalism as a historically and situationally conditioned ideology of ethnic identification that is typical of modern complex societies, regards culture and ethnicity as membership criteria, and postulates a common fate for its members. Thus, in Jenkins' view, nationalism has broader aims than trying to unify state and national boundaries.

\section{b. Critical discourse analysis}

Critical discourse analysis (CDA) builds upon the assumption that discourse is a social practice in dialectical relation to other social practices because it simultaneously constitutes them and is constituted by them, reproduces existing practices, and changes them at the same time (Jørgensen, Phillips 2002: 61-62). Discourses reflect the social world in the way their producers see it, while the same actors strive to achieve their ideological goals through the discourse they produce. Researchers affiliated to the CDA paradigm declare their will to reveal the role discursive practices play in maintaining and changing the social order, for which they use empirical textual analysis. In their view, the importance of language as an element of the social world is increasing; thus, it is necessary to study its use in order to learn about social processes (Fairclough 2003: 203-204).

The authors within CDA identify themselves with the tradition of critical social research. They express their will to reveal injustices in the social order and to seek possibilities for such changes that would help people out of poverty, deprivation and insecurity into rich and fulfilling lives (Fairclough 2003: 202). With respect to accusations that this approach is biased and not objective, Fairclough (2003: 14-15) answers that there is no such thing as objective, unbiased and exhaustive textual analysis and that socially involved motivation does not make CDA less scientific. To Van Dijk (1993: 253-254), CDA analysts cannot be distanced from, or neutral to the subject of their research because they always take the side of those who face oppression, discrimination, racism and prejudice.

As we can see, CDA primarily researches conflicts between the powerful and the powerless. Although the focus of this paper is a conflict between similarly powerful groups, it has a critical motivation as well. In the author's view, the political and economic elites on both the Bosniak and Bosnian Serb sides cannot run away from their responsibility either for the contents produced by the media under their control or, as a consequence, for their roles in nurturing nationalism as the main social problem in $\mathrm{BiH}$. The seriousness of the situation manifests itself in the absolute disagreement among the elites and the nations on a desirable 
way of organizing the Bosnian state, as well as on the causes and nature of the civil war in the 1990s. In 2005, the sociologist Ivan Vukoja (2005: 123) considered the structural causes to be unresolved. Since then the situation has only become worse.

The textual analysis itself, as designed by Fairclough (2003), begins with the identification of the social field and the social events the text refers to. In the text, genres are identified and the analysis deals with their activity (what is done through them), their orientation to various relations (power vs. solidarity), and the communication technologies that mediate them. Semantic and grammatical relations between clauses and sentences are analyzed, as well as the means of legitimization of the views expressed. Fairclough sees discourses (as a countable noun) as ways in which parts of the world are represented and he distinguishes them by their topics and by the occurrence and co-occurrence of words and of the semantic relations between them. Within a discourse, the researcher focuses on the inclusion or exclusion of elements of a social event (activity, persons, objects and others), on the means of their representation, and on the degree of their generalization on the scale: events $<$ series and sets of events $<$ social practices and structures. On the level of style, Fairclough proposes research into the presence of dialogues and of openness towards other opinions, modality as an expression of how much the author believes in her representation, and the presence of value judgments.

\section{Current Bosniak and Bosnian Serb media discourse on the 1990s civil war}

\section{a. The research sample}

The dailies Dnevni Avaz and Oslobođenje represent the Bosniak discourse in the research. According to the surveys mentioned above, they are likely to be the two most read newspapers among Bosniaks and, moreover, they represent both of the main Bosniak nation-related ideologies: the narrowly Bosniak conservative orientation and the manifestly antinationalist, civically pronounced Bosnian unitarism. These ideologies will be explained further on.

The Bosnian Serb discourse is analyzed through texts from the dailies Press $R S$ and Glas Srpske, which are the second and third most read newspapers in Republika Srpska. Press RS gives space to both the government and the opposition in RS, while Glas supports the current establishment, which has remained in power since 2006. Analyzing these two dailies ensures that the diversity of views on the civil war will be reflected, assuming that such diversity exists.

The researched texts concern those events connected to the war that are given attention by either the Bosniak or Serb newspapers or both pairs of newspapers. The analysis of the individual texts focuses on the following aspects: 
- The social events reflected in the text; the current and war events the text represents.

- The approach to difference from possible alternative representations. Polemic, openness to dialogue, the neglecting of differences.

- Intertextuality. The inclusion and exclusion of other voices.

- Semantic relations between clauses and sentences. Explanatory logic versus the logic of appearances.

- Representations of events' actors.

In the conclusion of the analysis, the individual discourses are identified and interpreted in relation to the Bosniak and Bosnian Serb nationalist ideologies. The analysis covers war-related events most discussed in the period from June 2013 to May 2014.

\section{b. The discourse on events related to the civil war}

“The White TAPes Day” In Prijedor, MAY / June 2013

On May 31, 2013 in Prijedor, Northern Bosnia, a rally took place to commemorate the 21 st anniversary of a local council's decree that had ordered non-Serb inhabitants to wear white armbands and to hang white sheets from their homes. Prijedor was under the control of the Army of Republika Srpska during the war and is now a part of RS.

Oslobodenje reported on the rally in an article entitled Not to forget Edna, Edin and 3173 innocent victims (Katana 2013). Several participants of the rally are quoted, as well as a petition addressed to the local council summarizing the demands of the rally organizers. The reporter represented "young people from all over the country", families of the victims, and activists from a civil initiative organized in Serbia and Croatia as the event's actors, concluding that such a scene was "good news". According to the text, the actors of the given war events were 3173 killed "people of non-Serb ethnicity", out of which 103 were Bosniak and Croat children. Those responsible for the crimes are not reported but the Prijedor local council is cited as the author of the white armband order. The current local council is represented as the addressee of the rally's demands and through their contents also indirectly as an actor responsible for discrimination of non-Serb war victims. Although the text does not give space to the Prijedor authorities' response, it avoids direct conflict with the other side by not mentioning the instigators of the war crimes, by indirectly recognizing the existence of Serb war victims, and also by not using the noun "aggression" for the Bosnian war, which is otherwise widespread in the Bosniak discourse. One can see similar features in a report on the same event by Avaz entitled Remembering the most loved ones can't be 
probibited (Dedic 2013). However, the title itself makes this text somewhat more conflictual towards the current Prijedor authorities and consequently towards the Serb side as a whole.

Glas Srpske and Press RS did not mention the rally.

DECLARATION ON THE NATURE OF THE WAR BY THE RS PARLIAMENT, JUNE 2013 On June 27, 2013 the RS National Assembly adopted "The Declaration on the Causes, Nature and Consequences of the Tragic Armed Conflict in BiH in 1992 1995" (Narodna skupština Republike Srpske 2013) proposed by several Serb parties and based on an initiative of the RS war veterans' organization. The adoption of the declaration is an act without legal effect and as such is a purely discursive event itself.

Press RS deals with the discussion about the declaration in the RS parliament in an article entitled Judgments of the Court of BiH to be revised (Press RS 2013a). In the report, the chairman of the Assembly and three Serb deputies are quoted directly, while critical Serb and Bosniak opposition voices are quoted indirectly. The text of the declaration itself is paraphrased by one deputy while the initiators of the declaration are not mentioned. A Serb opposition deputy Đerić legitimizes the declaration as a step towards the future as it, in his view, defines "what happened to us in the past". By us, he probably meant all inhabitants of $\mathrm{BiH}$ and not only Serbs, judging from his hope that the declaration will influence "what will be going on in BiH". We can therefore regard the words of the opposition deputy Đerić to be aimed at overcoming the differences between the views of the Bosnian nations. By using the impersonal expression "happened to us", he suggests that the war was triggered by an element foreign to Bosnian nations.

The commentary by Oslobodenje entitled Don't mention the cause of the war (Beric 2013) deals with both the declaration and the war itself. A number of times, the commentator stresses his distancing from the Serb view on the war when he openly argues against the RS veteran organization, against the text of the declaration, against the President of RS, and against the Serbs, first as a whole and then specifically against the Bosnian Serbs. In the author's opinion, the desire for reconciliation is a false reason for adopting the declaration: "The declaration came out of the veterans' organization so it looks like it has a good aim". The commentator paraphrases the declaration wrongly and in such a way that it is close to misinterpretation, saying that it "denies the genocide in Srebrenica", while the document in fact does not deal with this topic. He sees the RS President, Milorad Dodik, as the true initiator of the declaration ("there is a spirit of Milorad Dodik behind all that"), although he indirectly admits that the document expresses the opinions of the whole Serb nation of $\mathrm{BiH}$. When saying this, he might have used the words of the deputy Đerić who is known to us from the previous Press article: 
"The Serbs from this side of Drina (the river Drina makes up a large part of the border between $\mathrm{BiH}$ and Serbia - author's remark) like to say that this unlucky war 'happened' to us."

According to the author, the real reason for the declaration was President Dodik's fear of losing power, while the cause of the war had been "a storm of greater Serbian nationalism" started by Slobodan Milošević in 1989. The commentator ascribes the "criminal" founding of RS to both internal Bosnian Serb units and volunteers from Serbia. In contrast, the only role the Bosniaks played in the war was that of the victim of ethnic cleansing, concentration camps, rape, and the burning of villages. Thus, the commentator of Oslobodenje condemns both the authors of the declaration and its content, though partly incorrectly reproduced by himself. He instead presents his own, thoroughly different, representation of the Bosnian war.

\section{ANNIVERSARY OF THE MASSACRE OF BOSNIAKS IN SREBRENICA AND OF CRIMES AGAINST SERBS IN THE SURROUNDINGS OF SREBRENICA, JULY 2013}

In July 1995, the Army of Republika Srpska attacked the town of Srebrenica in Eastern Bosnia and afterwards killed thousands of Bosniaks in the surrounding area, mostly men, and deported even more women and children. The crime has been determined as genocide by a number of judgements of the Hague Tribunal. With about 8,000 killed, as stated by the Tribunal (UN ICTY, n.d.), it was the bloodiest single crime in the Bosnian war. The Bosnian Serb mainstream admits that a crime occurred but refuses to recognize it as genocide. In July, the Serbs commemorate two war events in villages near to Srebrenica. Bosnian Serb media speak of massacres of a total of 93 Serb civilians and soldiers committed by Bosniak units in 1992. At the same time, rallies take place to commemorate all the Serb war victims from the area (over 3,000 deaths are claimed). The Bosniak discourse ignores or denies these war events.

In the article entitled Cry from the shahid valley (Karić 2013), Oslobođenje reports about a commemorative rally near Srebrenica during which newly found victims were buried. It quoted parts of speeches of the international High Representative in $\mathrm{BiH}$, the US ambassador, a Turkish minister, and the Bosniak member of the Presidency of BiH. Survivors, Bosnian officials, and two Muslim clerics conducting ceremonies are among other participants that are mentioned. Oslobodenje does not speak about the participation of RS government officials, as mentioned by the Serb media. A number of elements of the text make its perspective explicitly Bosniak: the term shabid in the headline (a Muslim term for a martyr), the quoting of the Turkish minister (Turkey often represents itself as the Bosniaks' patron), and the expression "our people" used by one of the speakers to mean the Bosniaks. A number of times, the war event is called "genocide" while only in one quotation "a crime". The reporter and the quoted 
officials call the killed Bosniak civilians "the objects of the genocide" while those who committed the crime are only once represented in a vague manner by the noun "criminals." Two speakers stress the presence of "lies" about Srebrenica and the US ambassador classifies that as a "denial of genocide". Those suspected of the lies are not mentioned, but the accusations clearly target people among the Bosnian Serb community. Though implicitly, this text dealing with Srebrenica, views the Serbs exclusively in a conflictual light.

On the day of the anniversary, Avaz published a text from a historian Smail Čekic titled Srebrenica was a concentration camp of the UN where genocide was performed in public (Čekić 2013). The text almost entirely consists of the author's categorical assertions about the events of the war, which only twice very vaguely refer to some sources ("the results of previous scientific research," "numerous evidence"), while one can see no signs of dialogue with representations alternative to the author's ones. Čekić frequently connects sentences by additive relations and never by causal ones, giving the text a persuasive impression:

“The Dutch UNPROFOR battalion didn't even try to stop the aggressor's offensive on the UN safe zone of Srebrenica. It fiercely refused to react to the aggressor's offensive. It never responded to the Serb forces that had attacked the safe zone."

The persuasive goal of the author can be seen also from the 24 occurrences of the noun genocide and of words grammatically related to it. In the author's view, genocide concerned not only Srebrenica but also "all the occupied places and the surrounded towns of Republic of Bosnia and Herzegovina between the period of 1992-1995;" that is, all the territory where Serb or Croat units appeared. The Bosnian war is represented exclusively as aggression, while the noun war or other possible alternatives do not occur in the text. The historian regards Serbia as an aggressor (along with Croatia), as the occupier of Srebrenica, and also as the party guilty for the genocide. By contrast, the Bosnian Serb participants of the war are, in his view, merely "collaborators and a fifth column." The Bosniak political and military leadership does not take part in the historian's story, while the Republic of $\mathrm{BiH}$ and the Bosniak nation are the objects of the aggression and of the genocide, as the aggressor planned their "destruction" or "annihilation". The historian explains the aggression and the genocide very broadly by "the Serb and Croat nationalist ideology". Judging from the present tense he uses in elaboration of its goals, he probably sees the Serb ideology as persistent over time: "One of the strategic goals of the Serb nationalist ideology (...) is the Drina area". Čekić's text has a highly persuasive tone, implies equivalence between $\mathrm{BiH}$ and the Bosniaks, and accuses a permanent Serb nationalist ideology of the most brutal aims towards them.

Glas Srpske's report on the Bosniak commemoration was entitled 409 victims buried (Ćirković 2013). The text mentions the leader of the Islamic community in 
$\mathrm{BiH}$ and specifically three RS ministers out of all the participating delegations. In contrast to the Bosniak media, this article calls the war event a Serbo-Croat expression "stradanje", which means suffering or a death caused by violence. The only given component of the crime is "the Bosniak population of Srebrenica and the surroundings". Neither those guilty for the crime nor the number of victims are mentioned, which makes the representation of the 1995 Srebrenica events visibly reduced. Glas does not quote the parts of the speeches dealing with "genocide," "lies", or the denial of genocide found in Oslobođenje. Also, it does not mention the speech of the Turkish minister, although the Bosnian Serb media otherwise tend to stress and target the Turkish-Bosniak alliance. The exclusion of the Turkish speaker and the omission of parts of speeches incompatible with Serb mainstream opinion can be seen as a tendency to reduce the difference between the Bosniak and Serb interpretations. One might observe signs of dialogue with the Bosniak side, namely the length of the article, its prominence on the page, and the stress put on the participation of the RS delegation. However, the diminution of the elements of the Srebrenica war events goes in the opposite direction.

On the same page of Glas, right under the report of the Bosniak commemoration, a report entitled Today a commemoration for the killed Serbs (Glas Srpske 2013a) announces a gathering near to Srebrenica to commemorate an attack by "Muslim forces led by Naser Orić" on several Serb villages in 1992, during which "69 Serb civilians and soldiers" were killed. This war crime, of which the Serbs accuse the Bosniaks, is thus represented by Glas much more concretely than the Serb attack on Srebrenica. A few days before the Srebrenica anniversary, Press published a report on a commemoration of all the Serb victims of the Srebrenica region called They marginalize the Serbs (Press RS 2013b). Đokić, a minister in the RS government, is paraphrased, linking the crimes against the local Serbs and the war as a whole to the events of the Second World War:

“(...) Đokić (...) said that the Serbs had recognized the danger in time and hadn't let themselves be taken to concentration camps as had happened in 1941."

In this way, the Serb actions in the 1990s are legitimized by the fear that the crimes against the Serbs from the Second World War could have been repeated. Moreover, the effort to prevent them is declared successful. The paraphrased section indicates that, in minister Đokić's view, the same, yet unknown power that had sent the Serbs to concentration camps in the Second World War wanted to do the same in the 1990s. Apart from this quote, the report transmits the minister's dissatisfaction with the allegedly unjust investigation of the 1992-1995 war crimes, which is an element widely disseminated in the whole Serb discourse. 
ANNIVERSARY OF THE ESTABLISHMENT OF THE ARMY OF BIH AND OF THE ARMY OF REPUBLIKA SRPSKA, APRIL-MAY 2014

In the Bosniak environment, April 15 is celebrated as the anniversary of the establishment of the Army of the Republic of BiH (ARBiH) in 1992, which, contrary to its name, in reality remained an army representing only one of the three internal actors of the war. The Bosnian Serbs commemorate the establishment of the Army of Republika Srpska (VRS) on May 12.

Oslobođenje deals with a gathering to commemorate the ARBiH anniversary in a full-page report titled Remembering the foundation of $A R B i H$ (O Bender 2014). Three speakers are quoted: the $\mathrm{BiH}$ defense minister, the commander of a unit responsible for maintaining the traditions of the $\mathrm{ARBiH}$ within the current joint army, and a delegate of the Bosniak members of the BiH Presidency. At the very beginning, the formation of $\mathrm{ARBiH}$ is legitimized by the reporter as a response to "aggression" without stating the instigators of the aggression. Two speakers see the point of ARBiH's existence in defending the country, but just like the reporter they don't specify the adversary: the soldiers "gave their lives to (...) preserve Bosnia and Herzegovina," "honestly and in dignity defended their country," and "had only patriotism in their hearts." In a somewhat different manner, the reporter characterizes the struggle of $\mathrm{ARBiH}$ as one "liberating the people". Similarly, the defense minister asserts that, along with the abovementioned defense of $\mathrm{BiH}$, the soldiers gave their lives also for "our freedom." It is not clear whether the speakers referring to the people defended by $\mathrm{ARBiH}$ or to us mean all the people of $\mathrm{BiH}$ or Bosniaks only. The last speaker represents the role of ARBiH in a further different way:

"(...) we defended the belief that it is possible for the different religions and cultures in $\mathrm{BiH}$ to coexist, that all can live together."

This speaker allows his listeners to interpret who he means by we - it could be either members of ARBiH, mostly Bosniaks, or Bosniaks as a whole. One can interpret this sentence as meaning that the Bosniaks were trying to persuade the other two nations to accept the multiethnic idea through armed struggle (which is an unorthodox approach) and that they succeeded in this (which sharply contradicts the widespread objections to how the Serbs perceive the war). The factual problem with this statement is that if it is true that the Bosniaks really believed that "all [could] live together", it is hard to explain why they voted for the separation of $\mathrm{BiH}$ from Serbia in the 1992 referendum. This article concentrates on a number of internal dilemmas with which the Bosniak war-related discourse struggles.

Significantly more consistent in terms of the goals and adversaries of ARBiH in the war is an article by Avaz entitled $A R B i H$ is the biggest success of the patriots (Muhić 2014) consisting mostly of quotations from three generals of the former army. For all of them, ARBiH defended the state, be it expressed as "territorial 
integrity and sovereignty," "the borders," or "the idea of BiH as a state." General Ćuskić specifies the adversaries as VRS and the Bosnian Croat army, i.e. internal forces. He is then paraphrased, equating Bosnia and the Bosniaks using a historical abstraction in which $\mathrm{ARBiH}$ is "the biggest success of the Bosnian patriots and of the Bosniaks in military organization since the loss of independence in 1463." This text represents $\mathrm{BiH}$ as a nation-state of the Bosniaks and promotes patriotism and the defense of the country as the positive values of the war.

A month later, the anniversary of the Army of Republika Srpska (VRS) was celebrated in RS. In a report by Glas, The fighters will never be forgotten (Kuzaga 2014), quotations from official Serb speeches as well as reporter's assertions represent VRS as a defender of the Serb people and of Republika Srpska. However, no mention is made of who had attacked the Serbs and RS and for what reason. Instead, the Serb member of the BiH Presidency mentions "many untruths" that have been stated about the war and answers them in this way:

"The real truth is that VRS (...) is a successor of the famous and hard struggles for liberation that the whole Serb nation had been carrying on for centuries."

Thus, the politician uses the myth of the Serb liberation tradition as a legitimization of Serb activities in the Bosnian war. The text represents the Serb role in the last war as defensive but is very superficial about the adversaries of the Serbs, their actions and goals.

The force against which VRS defended RS is only slightly more specifically represented in words attributed to the RS President in an article in Press entitled $V R S$ was one of the most crucial factors in the formation of RS (Srna 2014b). In President Dodik's view, the Serbs and VRS resisted "those who wanted to endanger their freedom;" that is, VRS fought against the mere intention of an unspecified actor. The article's title paraphrases Dodik, who represents VRS in a more active, forming role, in contrast to the defensive representations in the report by Glas analyzed above.

\section{ANNIVERSARY OF THE ATTACK ON A JNA COLUMN IN SARAJEVO, MAY 2014}

On May 3, 1992, Bosniak armed units in Dobrovoljačka Street in Sarajevo attacked a column of the Yugoslav People's Army (JNA) that was withdrawing from the city in accordance with an agreement allowing safe passage for the JNA in exchange for the release of the captured president, Izetbegović. Serb sources state $42 \mathrm{JNA}$ soldiers killed. However, the figure includes victims of clashes of a disputed nature from the previous day; only between 4 and 9 fatalities are claimed for the Dobrovoljačka attack itself. The Bosnian Serb media, unlike the Bosniak kind, give this case considerable attention. 
A report by Glas entitled Justice has been waiting for 22 years (Domazet 2014a) deals with a gathering in Sarajevo to commemorate the abovementioned war event. The RS prime minister is quoted, calling the attack on JNA "a terrible bloody crime", while Mr. Zurovac, an author of a new book on this topic, expresses on behalf of the Serbs the following fear in an essentialist, historically abstract manner:

"It is not a problem that we, the Serbs, forgive, but that we also forget. Years are running, evidence disappearing and tomorrow we will again forget about our dead brothers in the name of some 'brotherhood and unity'."

The reporter categorically blames the then Bosniak political leadership for the attack and represents the event as "a peaceful retreat of JNA guaranteed by the UN." She, however, fails to mention that the other part of the agreement was the release of President Izetbegović, previously captured by JNA. She talks about 42 "cruelly killed" JNA members, yet an article published in Glas on the previous day, The wounds from Dobrovoljackea are not yet healed, shows that this number includes soldiers killed in other clashes, the nature of which is not elaborated upon in detail: "There was shooting at the army on the previous day when the JNA headquarters was attacked and all barracks were put under blockage. (...) 42 JNA members were killed (...)." This way of reporting the number of victims might be a purposeful manipulation of the facts in order to blow up the crime committed by the Bosniak side at the very beginning of the war.

\section{c. Proposal for the classification of discourses}

Under discourse (as a countable noun) Fairclough (2003) understands a representation of a certain aspect of the world in a certain way. Discourses are defined both by their topic and by the way they deal with it. Several discourses may occur within one text; they can also be used in a polemic between own and strange. Groups of topics can be understood as "orders of discourses" (Fairclough 2003) and, to a certain extent, as different social fields, inside of which the discourses compete with one another. Below, I propose the division of the topic of the Bosnian war as reflected in the Bosniak and Bosnian Serb media into individual discourses (see Figure 1). The size of the field of each discourse in the diagram represents the assumed frequency of its presence in the media. Where I feel the need to further demonstrate a particular discourse, I shall attach references to examples in the media. 
Figure 2: Individual discourses on the topic of the 1992-1995 war

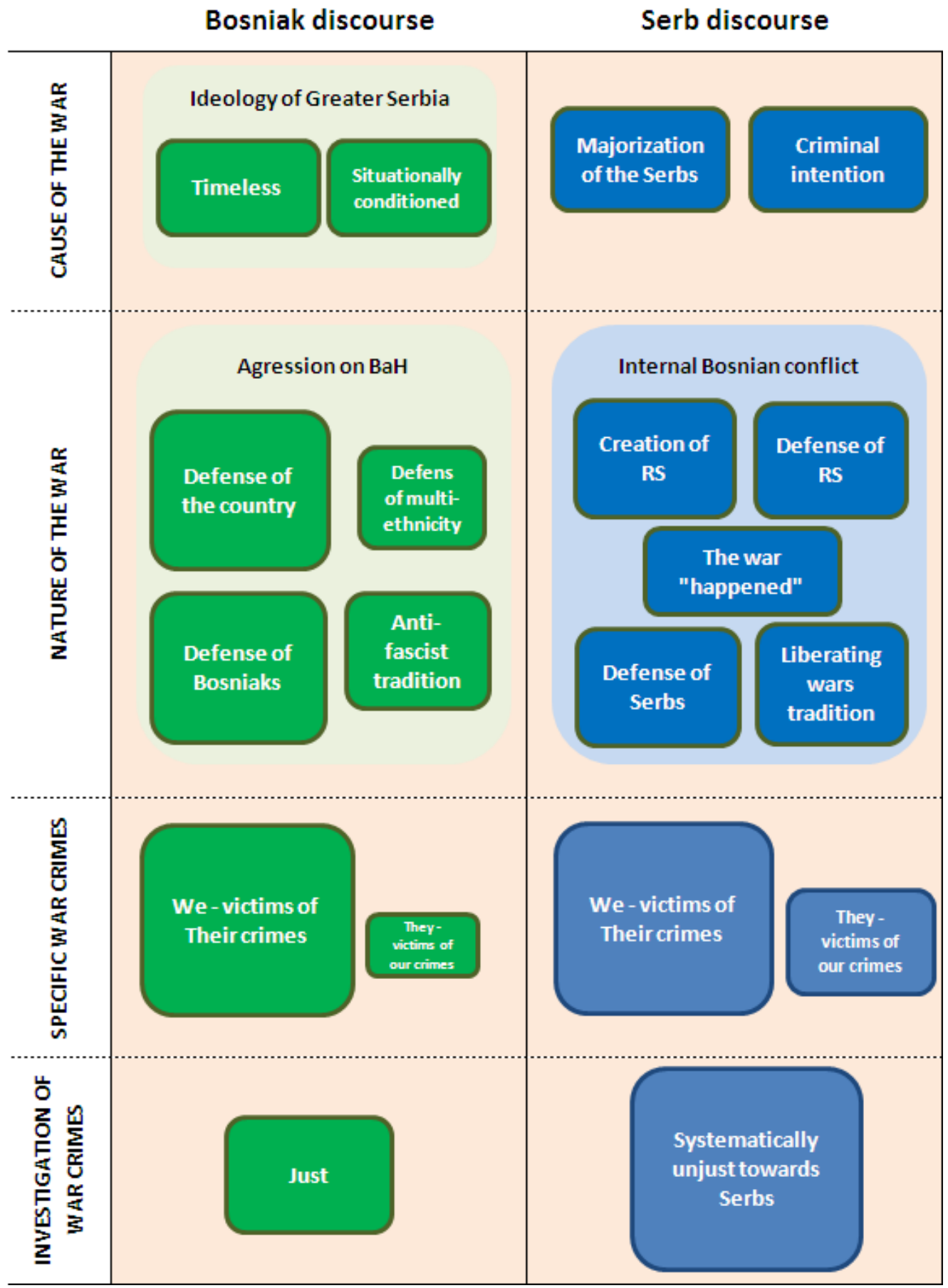

Source: author 


\section{CAUSES OF THE WAR}

Across the Bosniak media, the discourse of the greater Serbian ideology as the cause of the war predominates. According to the universally present Bosniak representation, the conflict began because the leadership of Serbia headed by Slobodan Milošević aspired to take the territory of $\mathrm{BiH}$ under its control. This discourse occurs in two versions. In one, the greater Serbian desire to expand into neighboring countries is timeless and inherent to the Serbs or at least to a great part of Serbian society. The other version is historically more specific, interprets the causes of the war merely within the period of Yugoslavia's breakup, and focuses on the power aspirations of the then Serbian president.

On the Serb side, one may identify two discourses on the causes of the war. One of them states that the war was caused by the majorization of the Serbs by the two other nations in the referendum on the separation of $\mathrm{BiH}$ from Yugoslavia. The Bosniaks and the Croats decided to secede despite the disapproval of the Serbs, by which they violated the Serbs' legal and moral right to sovereignly decide on their future - at the given moment, the right to remain united with Serbia. The other discourse assumes that individuals among the Bosniaks and the Croats or their leaderships had the intention to commit a crime against the Serbs and that the intended crime would have been similar to those committed by the Ustasha Croatia in the Second World War. This discourse is highly abstract when representing the actors to which it ascribes such criminal intention. As it makes no sense that the Bosniaks would react violently to their own criminal intention or to their own decision in the referendum, both Serb discourses on the causes of the war implicitly admit that the Serbs were the first to start the armed conflict.

\section{THE NATURE OF THE WAR}

The Bosniak media are united in representing the war as an aggression towards $\mathrm{BiH}$ led by Serbia in the first place and helped by the Bosnian Serbs as minor actors. They insist on the term "aggression" even when they cannot avoid representing the Bosnian Serbs as the main actors of certain events. Inside the "aggression" framework, further discourses on the nature of the war can be identified.

The discourse of the defense of $\mathrm{BiH}$ as a state emphasizes the sovereignty, territory, and borders of $\mathrm{BiH}$ as the values defended in the war. The aggressor strived to destroy the statehood of $\mathrm{BiH}$ but was prevented from doing so by Bosnian patriots and heroes. In this discourse, implicit tendencies to perceive $\mathrm{BiH}$ as the nation-state of the Bosniaks, mythologizing representations of Bosnian history and their projection into the present can be observed. A typical sign of this discourse is the formulation "they built their lives into BiH's foundations" referring to casualties from $\mathrm{ARBiH}$.

${ }^{2}$ Independence Day festively commemorated in Vogošća (Muračević 2014) 
A different understanding of the nature of the war presented in the Bosniak media is expressed in the discourse of the defense of the multi-ethnic nature of $\mathrm{BiH}$. From this perspective, the key value that the defenders of $\mathrm{BiH}$ fought for was the ethnic heterogeneity of the country while the aggressor was led by the ideology of separation and exclusivity. This discourse stresses examples of non-Bosniaks who fought on the Bosnian government's side and rejects manifest Bosniak nationalism ${ }^{3}$. It is more present in Oslobođenje than in Avaz.

The discourse of the antifascist nature of the defense of $\mathrm{BiH}^{4}$ projects the resistance of Yugoslav partisans from the Second World War into the 1990s Bosnian conflict. From this perspective, the enemy in the 1990s were fascists too and the Bosniak side was a successor to the anti-fascist struggle. This discourse is highly abstract when representing actors of the war.

The vast majority of texts in the Bosnian Serb media show the Bosnian war as an internal conflict without the direct involvement of Serbia. Compared to the Bosniak discourse on aggression, this representation is less concrete, as it avoids naming an instigator of the war and it represents the war actions of the other side in a vaguer way. Correspondingly, the noun war used in this discourse is more abstract than aggression. Similarly to the aggression discourse in the Bosniak media, more discourses can also be distinguished within this one.

According to the discourse of $R S$ creation, the Serb people and its army created RS in the war. Within this discourse, one can observe a widely used formulation "[they] built their lives in the foundations of RS," 5 which has a precise equivalent in the abovementioned Bosniak discourse of BiH's defense.

There can also be identified discourses of $R S$ defense and of the defense of the Serb people, both of which are characterised by a high degree of abstraction when representing the adversary and his offensive actions. Because of the fact that many non-Serbs lived on the present RS territory before the war, the discourse of the defense of the Serb people sometimes exhibits striking internal inconsistencies. This can be seen in a news report dealing with the town of Modriča, where the Serbs made up less than a quarter of its inhabitants in 1991:

"A memorial service for the killed fighters (...) commemorated 22 years after the beginning of a battle for the liberation of Modriča. (...) a participant of the operation Dragan Savić said that (...) on May 3, 1992 a unit of Serb volunteers had entered the town and liberated the Serb population.”6

\footnotetext{
${ }^{3}$ In a commentary The election potential of Naser Orić (Selimbegović 2014a) Željko Komšić (Croat) and Jovan Divjak (originally Serb), who both fought in ARBiH, are given as positive examples.

4 A place for the defenders (Hadžić 2014): "We have the duty to preserve the memory of the heroism of those who in 1992 didn't have a dilemma whether or not to fight fascism again."

${ }^{5}$ Remembering 205 killed fighters (Glas Srpske 2013b)

622 years since the liberation (Srna 2014a)
} 
In other cases, the Serb media present the Bosnian war in the context of the tradition of Serb wars of liberation, projecting not only Serb anti-fascist resistance from the Second World War but also idealized events from further in the past into the 1990s. This discourse is institutionalized in the existence of an RS government agency called The Committee for Preserving the Tradition of Wars of Liberation (Vlada Republike Srpske 2015).

The discourse of a war without an instigator implies that the war was started by an unknown force. It uses formulations such as "the war happened", "the war hit us", "tragic war conflict." This discourse has a somewhat larger potential for a dialogue with the other side than the ones previously mentioned.

\section{SPECIFIC WAR CRIMES}

The Bosniak and Serb discourses entirely ignore gatherings of the other nation commemorating war crimes committed against its members, excluding the Srebrenica massacre of Bosniaks, which the Serb media do reflect. Other war crimes of the other side are dealt with only in connection with their investigation.

In the Bosniak as well as Serb media the representation of $U s$ as the victims of Them prevails; that is, a specific crime committed by the other nation against ours is presented, which usually contains a concrete representation of those seen as guilty of the crime. The Bosniak version of this discourse states higher numbers of victims than the Serb one and deals with more extensive offences in larger towns and cities. Dissatisfaction with the investigation of a given crime is expressed in both versions, but more strongly in the Serb one. In the Bosniak discourse on specific war crimes, in contrast to the ones on the causes and nature of the war, Bosnian Serbs rather than Serbia are more often represented as actors. The word war is in this discourse preferred over aggression, which dominates in other Bosniak discourses.

A few examples of the discourse They as the victims of Our crimes can be observed in the Serb and Bosniak media. The Bosniak media represent almost exclusively only those crimes of Bosniaks against the Serbs that are under investigation. There are few of these and most of them are relatively less serious. Likewise, the Serb media, when representing crimes against Bosniaks, usually report only investigations concerning a larger number of graver crimes. The Serb media go beyond the framework of investigation in the case of the Srebrenica massacre. They, however, represent it in a reduced manner without specifying the guilty or the number of killed.

THE INVESTIGATION OF WAR CRIMES IN GENERAL

The Bosniak media do not pay much attention to an overall assessment of the investigation of war crimes. When they do, they usually express satisfaction with

7 The gravediggers of coexistence (Marković 2014) 
its justice and objectivity, largely in an implicit way using judgments on the Srebrenica genocide and other cases as authorization for their own views on the Bosnian war.

In contrast, Serb media often assess the investigation of war crimes by both the Hague Tribunal and local judiciary. They always harshly criticize systematic injustice towards the Serbs" and sometimes explicitly speak of "the anti-Serb nature" of the investigation ${ }^{10}$. International and local judiciaries are accused of unfair treatment of the Serbs, and parity between the suffering of the Serbs and the Bosniaks in the war is often implied.

\section{d. The relation of the identified discourses to nationalist ideologies}

Fairclough (2003: 9) understands ideologies as those representations of aspects of the world that "contribute to the constituting, maintaining and changing of relations of power, dominance and exploitation". When it comes to interpreting discourses as expressions of nationalist ideologies, this approach can be combined with Jenkins' concept of nationalism mentioned above, according to which nationalism is a situationally conditioned ideology that builds on ethnicity and culture, without necessarily striving for unification of the state and national borders.

Two main ideologies dealing with a desirable design for the Bosnian state are present among the Bosniaks. The first one, greater Bosniak nationalism, more or less openly claims the right of the Bosniaks to a nation-state within the current Bosnian borders and thus assumes the marginalization of Serbs and Croats into minorities. It is historically abstract, constructs an image of ancient Bosnian statehood, and, in its conservative version, stresses Bosniak cultural values. This ideology is similar to other European nationalisms and has significant potential to create conflict, given that the proportion of Bosniaks in $\mathrm{BiH}$ probably does not exceed $50 \%$.

The other Bosniak nation-related ideology can be called Bosnian unitarism. It postulates the equality of citizens, multiethnicity, and Bosnian identity, in some cases stretched to the full assimilation of Bosnian nations, as desirable foundations for $\mathrm{BiH}$. On the discursive level, Bosnian unitarism shows serious inconsistencies when it has to face the fact that it is very unpopular among the

\footnotetext{
${ }^{8}$ Militant Serbing (Kupusović 2014): "[VRS] committed thousands more crimes for which there are effective judgments of the International Court for Justice, of the Hague Tribunal for former Yugoslavia, as well as of local courts."

The Serbs aren't a genocidal nation (Hodžić 2014): “(...) structures from RS that carried out ethnic cleansing and that have been convicted for those crimes by local and international courts (...)"

${ }^{9}$ From inversion to perversion (Bižić 2013): "No one denies crimes against Bosniaks but the problem is that [chairman of Hague Tribunal] Theodor Meron and the like deny crimes against Serbs."

${ }^{10}$ They prefer Sejdic and Finci over Serbs of Sarajevo (Momić 2014).
} 
Serbs and Croats, with whom it wants to build a common Bosnian identity. This ideology has another internal problem in that it defends the separation of $\mathrm{BiH}$ from Serbia in 1992 while being unable to explain by its logic why the Serbs should live with the Bosniaks inside the borders of $\mathrm{BiH}$ and not in a state that would also include Serbia. Bosnian unitarism is sometimes a mere mask for the implementation strategy of the greater Bosniak nationalism, which makes it similar to the pro-Yugoslav reasoning by a part of the Serbian nationalist elite in the late 1980s and early 1990s. It is, however, not my intention to say that this is the case with all proponents of Bosnian unitarism.

In general, the Bosniak discourse as a whole frames the war in a bipolar way, ascribes full responsibility for starting it to the other side, and refuses to admit that any guilt resides on the Bosniak side. The Bosniak discourse is absolutely clear in all these questions as well as in its (hardly defendable) representation of the war as external aggression. Yet there are ideological differences within the Bosniak discourse. Texts nearer to greater Bosniak nationalism use historical projections and more conflictual statements of an essentialist nature. Such texts mostly use the discourse of a timeless greater Serbian ideology as the cause of the war and the discourses of the defense of the state and of the Bosniak people. In contrast, the discourses of a situationally conditioned greater Serbian ideology and the discourse of the defense of multiethnicity, both of which are closer to Bosnian unitarism, use more rational and historically more specific explanations, avoid essentialism, and are somewhat more open to dialogue. The antifascist tradition discourse is used by both ideologies, for it contains an ahistorical element as well as a multiethnic ethos.

A more difficult question is the relation of ideologies to the topic of specific war crimes in the Bosniak media. Some texts that use the discourse of $U s$ as the victims of Them have an ideological content of either type but others are less ideological. The latter represent those guilty of crimes as real persons, inhabitants of $\mathrm{BiH}$, rather than an abstract external aggressor, and presumably also use the term war more frequently than aggression. The rare discourse of Them as the victims of Us occurs more frequently in connection to Bosnian unitarism than to greater Bosniak nationalism.

In Dnevni Avaz, texts close to the greater Bosniak ideology were identified more often than in Oslobođenje, which, in turn, gives more space to Bosnian unitarism than Avaz. This, however, does not mean that the dailies are ideologically clear, also bearing in mind that the difference between the ideologies themselves is sometimes very blurred. A commentary by Oslobođenje entitled I am sorry for the Army (Selimbegović 2014b) demonstrates this. A journalist, Vildana Selimbegović, who elsewhere defends multiethnicity and rejects Bosniak nationalism, in this article identifies herself with general Ćuskić, quoted in one of Avaz's texts mentioned above equating $\mathrm{BiH}$ with the Bosniaks. 
Nevertheless, it can hardly be seen as good news that the more radical representations relating to greater Bosniak nationalism occur more often in Avaz, which has larger sales than Oslobođenje. Thus, Avaz has remained faithful to Bosniak conservative nationalism ever since the war and enjoys a large readership among Bosniaks. Oslobođenje maintains its manifestly liberal pro-Bosnian identity, and so reaches probably only to the urban Bosniaks of higher education, while being unable to engage any significant part of the Serb or Croat readership.

Serb nationalism as an ideology can be seen as one whole with two levels. Its milder version defends the territorial autonomy of the Serbs in $\mathrm{BiH}$, while the more radical one demands separation from $\mathrm{BiH}$ and possibly unification with Serbia. No clear boundary between the two levels can be identified, as proponents of the Serb nationalist ideology may sometimes follow the goal of separation masked by the defense of autonomy ${ }^{11}$.

The Serb discourse uses historical and emotional explanations of 1990s war events more often than the Bosniak form. It represents the actions of our side as legitimate while it reduces the overall war activity of the Bosniaks to criminal intentions towards Serbs without mentioning any real major criminal action; it even claims that such action was successfully prevented. The activities of the Bosniaks are reported at the lower level of specific war crimes of a relatively limited extent.

With respect to the causes of the war, the discourse of the majorization of the Serbs is firmly factually grounded in the decision of the Bosniaks and Croats to separate $\mathrm{BiH}$ from Yugoslavia. However, probably realizing that this is not a sufficient argument to legitimize the instigation of the war, the discourse of the enemy's criminal intention is also frequently used. This argument could have a greater legitimizing power if it was proven, yet its users usually imply the existence of criminal intentions on the part of a fuzzily-defined adversary by means of the mere projection of crimes committed against the Serbs in the Second World War into the present. Hence, this claim lacks any ounce of credibility. The criminal intention discourse falls into the more radical version of Bosnian Serb nationalism, while the majorization discourse is closer to the moderate kind.

Radical Bosnian Serb separatism, which assumes the impossibility of coexistence between the Serbs and the other Bosnian nations on a common territory, also manifests itself in the discourses of RS creation and in the mythologically loaded discourse of the Serb tradition of liberation. The discourse

\footnotetext{
${ }^{11}$ In the commentary The gravediggers of coexistence (PRS, February 1, 2014, p. 2), the author says that Bosniak politicians "will cause the breakup of the country by [their] actions", by which he implies that the breakup is not a Serb desire. However, another formulation in the same text ("They have forever closed the door to a new trust between the nations that they wanted to reach") implies that the Serbs or the commentator himself actually never tried to affirm coexistence in $\mathrm{BiH}$.
} 
the war happened might signalize the readiness of its user to admit that Serbs share some of the responsibility for the war; thus, it might belong to the less radical version of the Serb nationalist ideology. Similarly, some of the texts reflecting on Bosniak commemorations of the Srebrenica crime go halfway to admitting a portion of the guilt. This is the only case of mutual recognition of remembrance of victims that has been observed within the present analysis.

The discourse of unjust war crimes investigations does not have a clear ideological residence but it can be seen as one of the factually stronger ones. Since its foundation, the Hague tribunal, which covers all the post-Yugoslav conflicts, has convicted almost exclusively Serbs, and the local Bosnian judiciary, managed by central authorities, usually investigates only less serious crimes committed against Serbs. In contrast, up until recently, Serb convicts were punished retroactively according to the $\mathrm{BiH}$ criminal code from 2003 (European Court of Human Rights 2013), which is harsher than the code valid for the period of the war itself.

In Press RS, expressions of radical Serb separatism were identified more often than in Glas Srpske. A number of Press commentaries imply the impossibility of coexistence in $\mathrm{BiH}$ and use unreasoned statements in favor of the Serb view of the war. In Glas Srpske, one can identify a significant number of texts on the war events that could arguably have a potential for dialogue with the other side.

\section{Conclusion}

Nearly twenty years after the end of the war, within both Bosniak and Bosnian Serb political elites, we find complete concordance on the view that the other side caused the war and that their own side was merely defending itself against a real or intended crime. The media influential inside each nation continue to reflect this internal harmony and carry on the narrative that the 1990s civil war was a struggle between good (Us) and evil (Them). Concerning the causes of the war, they believe that their own side was entirely innocent and that guilt resides wholly on the other side of the former front line, which is now a boundary between the Bosnian entities. They ignore the people killed on the opposite side, either implying that all the witnesses and relatives of the victims are lying or being manipulated.

When it comes to facing their own role in the war, the Serbs are in a worse situation. The Bosnian Serb media fail to hide the fact that the war was initiated by Serb military action and that the Serbs committed graver crimes against the Bosniaks than the other way round. They offer a highly abstract image of the beginning and of the course of the war, especially when defining the enemy against which the Serb side "defended" itself, and often legitimize Serb war actions by events decades or even centuries old. The Serb media even implicitly admit that the Serb side started the war and that it subsequently committed more 
serious crimes by means of the narratives about majorization as the cause of the war and about the thwarted criminal intention of the enemy, and by highlighting the case of a few Yugoslav soldiers killed in Sarajevo as the prominent Bosniak crime. However, the proponents of the Bosnian Serb nationalist ideology, in their desire for separation from the Bosniaks and Croats, have a strong ally in the lack of will of the international and local judiciaries to prosecute those crimes against Serbs that go beyond the killing of a few individuals; thus, in a position of weakness, they can always retreat under the cover of this safe discursive refuge. Yet this is where the nationalists are not alone. Justice for Serb victims and the Bosniaks' recognition of their own war crimes are awaited also by those Serbs who are perhaps more willing to engage in open dialogue, even if they themselves are still far from initiating it.

The Bosniaks debate the war in a more confident and concrete manner, aware of their factual superiority in the crucial questions and also of the sympathy of influential Western foreign countries towards their view of the war. On the other hand, the Bosniaks have to face more problems than the Serbs regarding the linkage of the war-related discourse to the future. While the more radical branch of the Serb nationalist ideology, given its separatist vision, does not need to reach agreement with the Bosniaks about the nature of the war, virtually all Bosniaks wish their state to remain preserved in the current borders that also include the Serbs. Those among them who sincerely want to reach this goal in another way than by marginalizing Serbs into an ethnic minority should strive to align the Bosniak and Serb views on the tragedy of the past more closely. However, up to now, no one on the Bosniak side, including producers of the more moderate, manifestly multicultural discourse, has been willing to discuss whether it was legitimate to decide on the separation of $\mathrm{BiH}$ from Yugoslavia against the will of the entire Serb nation of $\mathrm{BiH}$. Instead, by universally using the "aggression" discourse, which mistakenly places the Bosnian Serbs into the passive role of the executors of the will of an outside force (if not, in the worse case, into the role of guests on Bosniak territory), the Bosniak media demonstrate a deep misunderstanding of the fears and desires of the Serbs in BiH in the 1990s as much as of the current ones. Even so, one can also find potential future initiators of such a discussion among Bosniaks. Maybe they, or someone similar on the Serb side, will one day find the courage to step forward.

The analysis aimed at identifying specific strategies regularly used within both national discourses in legitimizing the role of their own nation in the war. Apart from the gap between the Bosniak and Bosnian Serb media, it also finds differences within the national contexts depending on how much of the radical type of nationalism a specific discourse can be linked to. Future research might follow up these findings in a number of directions. First of all, adding the Croat perspective to this analysis is more than desirable. In addition, Bosnian media content would certainly be better understood by researching other topics than the 
1990s war, the Bosnian media's relationship to the ownership of individual media outlets, and its power background; and also by analyzing the interaction between Bosnian media content and public opinion. In this way, the potential of critical discourse analysis as a multidisciplinary paradigm striving to understand the complex relation between language and social dynamics and oriented towards achieving positive social change in connection to the situation in Bosnia and Herzegovina would be fully exploited.

\section{List of abbreviations}

ARBiH Army of the Republic of Bosnia and Herzegovina (army of the Bosniak side in the Bosnian war)

$\mathrm{BiH} \quad$ Bosnia and Herzegovina

CDA Critical discourse analysis

$\mathrm{FBiH} \quad$ Federation of Bosnia and Herzegovina (entity proclaimed by Bosniak and Bosnian Croat representations, later recognized as entity within Bosnia and Herzegovina)

JNA Yugoslav People’s Army

RS Republika Srpska (proclaimed as a state by the Bosnian Serbs, later internationally recognized an entity within Bosnia and Herzegovina)

VRS Army of Republika Srpska

\section{Bibliography}

Barth, Fredrik (1969). Ethnic groups and boundaries. Boston: Little, Brown.

Behram, Mirsad (2014). "Deceniju poslije: Stari most (ni)je povezao dvije strane u Mostaru." Radio Slobodna Evropa, 23. 7. 2014, on-line (http://www.slobodnaevropa.org/content/deceniju-poslije-stari-most-nije-povezadvije-strane-u-mostaru/25466436.html) [Accessed 27 Apr. 2015].

Bender, Fahrudin (2014). "Sjećanje na nastanak Armije BiH / Remembering the foundation of ARBiH". Oslobodenje, April 16, 2014, p. 7.

Berić, Gojko (2013). "Uzrok rata ne pominjati / Don't mention the cause of the war". Oslobodenje, June 27, 2013, p. 10.

Bižić, Saša (2013). "Od inverzije do perverzije / From inversion to perversion”. Press RS, July 13, 2013, p. 2.

Cekić, Smail (2013). "Srebrenica je bila koncentracioni kamp UN-a u kojem je genocid vršen javno / Srebrenica was a concentration camp of UN where genocide was performed in public". Dnevni Avaz, July 11, 2013, p. 6-7.

Ćirković, Krstina (2013). "Ukopano 409 žrtava / 409 victims buried”. Glas Srpske, July 12, 2013, p. 4.

Dedić, M. (2013). "Sjećanja na najmilije ne mogu se zabraniti / Remembering the most loved ones can't be prohibited". Dnevni Avaz, June 1, 2013, p. 9. 
Domazet, Željka (2014a). "Pravda čeka 22 godine / Justice has been waiting for 22 years". Glas Srpske, May 4, 2014, p. 2.

Domazet, Željka (2014b). "Rane iz Dobrovoljačke još nisu zacijelile / The wounds from

Dobrovoljačka are not yet healed”. Glas Srpske, May 3, 2014.

Državni zavod za statistiku Republike Bosne i Hercegovine (1993). Nacionalni sastav stanovnistva: Rezultati za republiku po opśtinama i naseljenim mjestima. Sarajevo.

Džihana, Amer, Čendić, Kristina and Tahmaz, Meliha (2012). Mapping Digital Media: Bosnia and Herzegovina: A Report by the Open Society Foundations. Open Society Foundations, on-line (http://www.opensocietyfoundations.org/sites/default/files/mapping-digitalmedia-bosnia-20120706.pdf) [Accessed 20 Feb. 2015].

European Court of Human Rights, (2013). Predmet Maktouf $i$ Damjanovic protiv Bosne $i$ Hercegovine - presuda. Strasbourg, on-line

(http://www.mhrr.gov.ba/PDF/UredPDF/default.aspx?id=3989\&langTag=bs-BA) [Accessed 27Apr. 2015].

Fairclough, Norman (2003). Analysing discourse. London: Routledge.

Filipović, Najdan (2013). "Statistički podaci iz "Bosanske knjige mrtvih" prezentirani prema istraživanjima Mirsada Tokače direktora Istraživačko dokumentacionog centra (IDC) u Sarajevu", BH Magazin, 25. 1. 2013, on-line

(http://web.archive.org/web/20130131121435/http://www.bhmagazin.com/kolumne /bosanskilonac/item/11023-statisti\%C4\%8Dki-podaci-iz-bosanske-knjige-mrtvihprezentirani-prema-istra $\% \mathrm{C} 5 \%$ BEivanjima-mirsada-toka $\% \mathrm{C} 4 \% 8 \mathrm{De}$-direktora-

istra $\% \mathrm{C} 5 \% \mathrm{BEiva} \% \mathrm{C} 4 \% 8 \mathrm{Dko}$-dokumentacionog-centra-idc-u-sarajevu.html) [Accessed 27 Apr. 2015].

Glas Srpske (2013a). "Danas pomen za ubijene Srbe / Today a commemoration for the killed Serbs". Glas Srpske, July 12, 2013, p. 4.

Glas Srpske (2013b). "Sjećanje na 305 poginulih boraca / Remembering 205 killed fighters". Glas Srpske, June 12, 2013, p. 10.

Hadžić, Almasa (2014). "Mjesto za branioce / A place for the defenders". Dnevni Avaz, April 7, 2014, p. 3.

Hodžić, Dževad (2014). "Srbi nisu genocidan narod / The Serbs aren't a genocidal nation". Oslobođenje, May 2, 2014, p. 10.

Istinito (2013). "Kojim medijima građani BiH najviše vjeruju." 17. 6. 2013, on-line (http://www.istinito.com/index.php/aktuelno/item/9240-kojim-medijima-gradani-bihnajvise-vjeruju.html) [Accessed 20 Feb. 2015].

Jenkins, Richard (1997). Rethinking ethnicity. London: Sage.

Jørgensen, Marianne and Phillips, Louise (2002). Discourse analysis as theory and method. London: Sage Publications.

Jusić, Tarik (2009). "Media discourse and the Politics of Ethnic Conflict: The Case of Yugoslavia." In: P. Kolstø, ed., Media Discourse and the Yugoslav Conflicts, 1st ed. London: Ashgate, 21-38.

Karić, S. (2013). "Krik iz doline šehida / Cry from the shahid valley". Oslobodenje, July 12, 2013, p. 2.

Katana, Gordana (2013). "Da se ne zaborave Edna, Edin i 3173 nevine žrtve / Not to forget Edna, Edin and 3173 innocent victims". Oslobodenje, June 1, 2013, p. 2-3.

Kolstø, Pål (2009). Media Discourse and the Yugoslav Conflicts. London: Ashgate.

Kordić, Snježana (2010). Jezilk i nacionalizam. [Zagreb]: Durieux. 
Kupusović, Sulejman (2014). "Militantno Srbovanje / Militant Serbing". Dnevni Avaz, May 17, 2014, p. 10.

Kurspahić, Kemal (2003). Zločin u 19:30. Beograd: Dan Graf.

Kuzaga, Vedrana (2014). "Borci nikada neće biti zaboravljeni / The fighters will never get forgotten". Glas Srpske, May 13, 2014, p. 2.

Marko, Davor (2010). Izvještavanje u interesu političkih elita. Novi pogledi 17: 34-37.

Marković, Žarko (2014). "Grobari suživota / The gravediggers of coexistence”. Press RS, February 1, 2014, p. 2.

Momić, Darko (2014). "Sejdić i Finci im preči od sudbine sarajevskih Srba / They prefer Sejdić and Finci over Serbs of Sarajevo". Press RS, January 14, 2014, p. 3.

Muhić, S. (2014). "ARBiH je najveće dostignuće patriota / ARBiH is the biggest success of the patriots". Dnevni Avaz, April 15, 2014, p. 8-9.

Muračević, Eset (2014). "U Vogošći svečano obilježen Dan nezavisnosti / Independence Day festively commemorated in Vogošća". Dnevni Avaz, March 1, 2014, p. 5.

Narodna skupština Republike Srpske, (2013). Deklaracija o urrocima, karakteru i posljedicama tragičnog oružanog sukoba u Bosni i Hercegovini od 1992. do 1995. godine. Banja Luka.

Nikolić, Maja (2013). "Građanima BiH prijeti još veće siromaštvo.” Radio Slobodna Evropa, 19. 10. 2013, on-line (http://www.slobodnaevropa.org/content/gradjanima-bih-prijetijos-vece-siromastvo/25141698.html) [Accessed 27 Apr. 2015].

Press RS (2013a). "Presude Suda BiH na reviziju / Judgments of the Court of BiH to be revised". Press RS, June 27, 2013, p. 3.

Press RS (2013b). "Srbe umanjuju / They marginalize the Serbs". Press RS, July 7, 2013, p. 5.

Puhalo, Srđan (2009). Etnička distanca i (auto)stereotipi gradana Bosne i Hercegovine. Sarajevo: Friedrich Ebert Stiftung.

Sadiković, Mirna (2012). "Boljke medija u BiH: Ovisnost, pritisci i govor mržnje." Radio Slobodna Evropa, 6. 3. 2012, on-line

(http://www.slobodnaevropa.org/content/boljke_medija_u_bih_ovisnost_pritisci_i_g ovor_mrznje/24506932.html) [Accessed 27 Apr. 2015].

Selimbegović, Vildana (2014a). "Izborni kapacitet Nasera Orića / The election potential of Naser Orić". Oslobođenje, February 3, 2014, p. 10.

Selimbegović, Vildana (2014b). "Zao mi Armije / I am sorry for the Army". Oslobođenje, April 21, 2014, p. 6.

Srna (2014a). "Obilježeno 22 godine od oslobođenja / 22 years since the liberation”. Glas Srpske, May 4, 2014, p. 4.

Srna (2014b). "VRS je bila jedan od presudnih faktora stvaranja Republike Srpske / VRS was one of the most crucial factors of forming of RS". Press RS, May 12, 2014, p. 3.

Srna, (2014c). "Najveća stopa nezaposlenosti u BiH." Nezavisne novine, 1. 5. 2014, on-line (http://www.nezavisne.com/posao/analize/Najveca-stopa-nezaposlenosti-u-BiH242906.html) [Accessed 27 Apr. 2015].

Tanjug, (2014). "BiH: Siromašno dve trećine građana." Novosti.rs, 9. 6. 2014, on-line (http://www.novosti.rs/vesti/planeta.300.html:495377-BiH-Siromasno-dve-trecinegradjana) [Accessed 27 Apr. 2015].

Tešanović, Nada (2012). Balkanski medijski barometr: Bosna i Hercegovina 2011. Sarajevo: Friedrich-Ebert Stiftung.

Thompson, Mark (2000). Proizuodnja rata. Beograd: Medija centar. 
Turčilo, Lejla (2010). "Bosanski mediji zaista oslikavaju podijeljenost društva: Balkan Insight.” Balkaninsight.com, on-line (http://www.balkaninsight.com/en/article/bosanskimediji-zaista-oslikavaju-podijeljenost-drustva) [Accessed 25 Apr. 2015].

Udovičić, Radenko (2010). Iźbori 2010. u BiH. Sarajevo: Media plan institut.

UN ICTY, (n.d.). The Conflicts, on-line (http://www.icty.org/sid/322) [Accessed 27 Apr. 2015].

van Dijk, Teun (1993). Principles of Critical Discourse Analysis. Discourse and Society, 4(2): 249-283.

Vlada Republike Srpske (2015). Сутра обивежавағье страдапь Срба у Сијековиу 1992. Године. Vladars.net, 25. 3. 2015, on-line (http://www.vladars.net/sr-SPCyrl/Vlada/Ministarstva/mpb/media/aktuelnosti/Pages/sijekovac-sutra.aspx) [Accessed 2 May 2015].

Vukoja, Ivan (2005). "Društvene i političke elite u BiH - pitanje odgovornosti." STATUS magazín za politickeu kulturu $i$ društvena pitanja, 7: 123-137.

Zebić, Enis (2013). "U Zagrebu predstavljena Bosanska knjiga mrtvih." Radio Slobodna Evropa, 28. 5. 2013, on-line (http://www.slobodnaevropa.org/content/u-zagrebupredstavljena-bosanska-knjiga-mrtvih/24999848.html) [Accessed 20 Feb. 2015].

Zwierzchowski, Jan and Tabeau, Ewa (2010). "The 1992-95 War in Bosnia and Herzegovina: Census-Based Multiple System Estimation of Casualties' Undercount." Conference Paper, Berlin, on-line

(http://www.icty.org/x/file/About/OTP/War_Demographics/en/bih_casualty_under count_conf_paper_100201.pdf) [Accessed 20 Feb. 2015]. 